\title{
Correction to: Biaxial bending of SFRC slabs: Is conventional reinforcement necessary?
}

\author{
Marco di Prisco (D) Matteo Colombo - Ali Pourzarabi
}

Published online: 12 December 2019

(C) The Author(s) 2019

\section{Correction to: Materials and Structures (2019) 52:1 https://doi.org/10.1617/s11527-018-1302-0}

The article "Biaxial bending of SFRC slabs: Is conventional reinforcement necessary?", written by Marco di Prisco, Matteo Colombo and Ali Pourzarabi, was originally published electronically on the publisher's Internet portal (currently SpringerLink) on 22 December 2018 without open access.

The copyright of the article changed in December 2019 to (C) The Author(s) 2019, and the article is forthwith distributed under the terms of the Creative Commons Attribution 4.0 International License (http://creativecommons.org/licenses/by/4.0/), which permits use, duplication, adaptation, distribution and reproduction in any medium or format, as long as you give appropriate credit to the original author(s) and the source, provide a link to the Creative Commons license and indicate if changes were made.

Open Access This article is distributed under the terms of the Creative Commons Attribution 4.0 International License (http:// creativecommons.org/licenses/by/4.0/), which permits unrestricted use, distribution, and reproduction in any medium, provided you give appropriate credit to the original author(s) and the source, provide a link to the Creative Commons license, and indicate if changes were made.

Publisher's Note Springer Nature remains neutral with regard to jurisdictional claims in published maps and institutional affiliations.
The original article can be found online at https:// doi.org/10.1617/s11527-018-1302-0.

M. di Prisco $(\varangle) \cdot$ M. Colombo · A. Pourzarabi Department of Civil and Environmental Engineering, Politecnico di Milano, Milan, Italy e-mail: marco.diprisco@polimi.it 